\title{
RNA splicing for 30 years
}

\author{
SOO-CHEN CHENG \\ Institute of Molecular Biology, Academia Sinica, Nankang, Taipei 115, Taiwan
}

Thirty years ago, I joined John Abelson's lab and started my RNA research career. It was the time that RNA splicing was a revolutionary discovery, and people craved to understand the details of the process. My mission was to develop an in vitro splicing system in yeast so that the mechanism of the splicing reaction could be studied. Andy Newman had developed an oligo protection assay for detecting the spliced mRNA to assay for splicing. I was prepared for a long fight having learned that many efforts have been tried by several people but not a bit of activity had been detected from numerous extracts prepared. Luckily, I was there to witness the excitement of the first detection of the splicing activity when it happened totally unexpectedly within a month of my arrival. Studies from the mammalian systems had provided some clues for us to follow, such as the ways of making extracts and the conditions of the splicing assay. The splicing reaction in mammalian extracts was known to be slow, in the scale of hours. Therefore, every try of the splicing assay had started from $1 \mathrm{~h}, 2 \mathrm{~h} \ldots$ and so on. Everybody seemed to believe that when the activity was low, the only way to see it was to carry out the reaction for a long time. It was most amazing that one day Andy decided to go for $20 \mathrm{~min}, 40 \mathrm{~min}$, and $1 \mathrm{~h}$ in his assay for unknown reasons, and for the first time a tiny amount of spliced product was detected at the time point of $20 \mathrm{~min}$, a trace amount at $40 \mathrm{~min}$, but none at $1 \mathrm{~h}$. It turns out that splicing in yeast extracts is much faster than in mammalian extracts, and nucleases in yeast extracts can degrade the RNA or the protected oligo after long incubation. Although the way of making extracts was somewhat different, this switch of mind I believe was the turning point of the whole business, and of my career. I have always remembered this, and along the years, this has been an important guidance for my research in solving problems and puzzles by thinking in an unconventional way.

In the early years, most efforts in understanding the mechanism of mRNA splicing focused on the small nuclear RNAs for clear reasons. Very little was known about the functions of the protein components. People had started fractionating extracts for identification and purification of splicing factors, and yeast researchers further had taken genetic approaches to screen for genes encoding protein factors to understand

Corresponding author: mbscc@ccvax.sinica.edu.tw

Article and publication date are at http://www.rnajournal.org/cgi/doi/ 10.1261/rna.050021.115. Freely available online through the RNA Open Access option. their roles in the splicing reaction. Being trained as a nucleic acid enzymologist, I set out to characterize protein components of the splicing machinery when I started my own lab at the Academia Sinica in Taiwan, taking advantage of the splicing mutants isolated in John's lab. The first protein we characterized, Prp19, turned out to be complicated and is more than just a protein. Prp19 is associated with several proteins to form a complex, the NTC for nineteen complex, for its function, and could not be reconstituted with a recombinant protein. It took us some years to identify core components of the NTC and understand the role of the NTC in the splicing reaction. The NTC is one of the few essential protein factors that remain stably associated with the spliceosome until completion of the reaction, at least in yeast. It is required for spliceosome activation, and also serves as a platform for proteinprotein and protein-RNA interactions, much like a multisubunit structure of Brr2 or Prp8. Nevertheless, the NTC is extremely dynamic, making structural study a difficult task. Proteomic studies have revealed many other proteins to associate with the NTC, possibly due to dynamic interactions of these proteins with the NTC core complex. Several of these proteins, identified as CWC components, have turned out to be involved in the first catalytic reaction rather than activation of the spliceosome, suggesting a functional link of the NTC with the first catalytic step.

It is clear that during the catalytic step, the spliceosome is extremely dynamic both compositionally and conformationally. Several proteins interact with the spliceosome transiently to mediate structural changes of the spliceosome, and ATP is required for both catalytic steps. Understanding how the structure changes in the spliceosome during the catalytic step is key in understanding the mechanism of the splicing reaction. Spliceosomal introns and group II introns are believed to be evolutionarily related, not only for their identical catalytic strategy, but also for their similarity in the RNA structure in the catalytic core. Crystal structures of several group II intron variants have been determined to reveal how the structural elements interact, how the catalytic residues are positioned, and how the conformation is switched between the two catalytic steps. The spliceosome is much more complicated than group II introns with proteins

(C) 2015 Cheng This article, published in RNA, is available under a Creative Commons License (Attribution-NonCommercial 4.0 International), as described at http://creativecommons.org/licenses/by-nc/4.0/. 
binding to stabilize the structure and mediate structural changes of the RNA. Structural rearrangements of RNA during the transition between the two catalytic steps have been studied primarily by mutational analysis of RNA residues in or near the catalytic center. Based on the genetic data, both U2 helix II and U2/U6 helix I have been proposed to rearrange their structures during the transition from first to second catalytic step, and DExD/H-box protein Prp16 is further proposed to mediate unwinding of the U2/U6 helix I during the transition. How splice sites are repositioned remains unknown. Notably, mutations of RNA residues may also affect the interaction of RNA with protein components, and mutations in the protein components can also affect the stability of the RNA structure. Prp16 is shown to promote destabilization of the key component required for the first catalytic reaction, Cwc25, and whether destabilization of Cwc25 leads to destabilization of U2/U6 helix I or vice versa remains unclear. It is important to determine the structure of the spliceosome intermediate complexes to elucidate how the structure changes in the catalytic core of the spliceosome during the transition between two steps.

The identification and characterization of protein factors involved in each catalytic step has allowed further dissection of the structural changes in the catalytic spliceosomes. One common feature of the proteins involved in the catalytic steps is that they only associate with the spliceosome transiently, in a way of "come and act and go." These proteins therefore only associate with specific intermediate complexes, and can serve as markers for those complexes. Using these proteins as tools, it will be possible to isolate specific complexes to homogeneity for structural studies. On determining the structure of the catalytic spliceosome, it is important to bear in mind that the spliceosome is not only structurally dynamic, but also chemically dynamic. Once fully assembled and activated, the catalytic spliceosome can undergo reversible splicing reactions and also catalyze hydrolytic debranching and SER (spliced-exon reopening) reactions depending on the ionic environment. Thus, the chemical reactions may occur on purified spliceosome species under conditions necessary for crystallization or for structural analysis, and ultimately result in a mixture of different conformations of the spliceosome. Modification in the structure of the protein components that bind at the catalytic center of the spliceosome to prevent the catalytic reaction from taking place will be necessary to maintain a homogeneous population of specific complexes.
How the spliceosome is disassembled is another big issue to be solved. After completion of the splicing reaction, the mature mRNA is first released, and the spliceosome is then disassembled to recycle its components. The process is mediated by $\mathrm{DExD} / \mathrm{H}$-box protein $\operatorname{Prp} 43$ in association with the NTR complex, which additionally contains Ntr1 and Ntr2. Spliceosome disassembly can be assayed in vitro using purified terminal-stage spliceosome and purified NTR complex or recombinant proteins. The addition of purified NTR components and ATP to the spliceosome results in complete disassembly of the spliceosome, with individual components, U2, U5, U6 and NTC totally separated from lariat-intron as naked RNA. The process is energy consuming, involving disruption of many RNA-RNA, RNA-protein, and proteinprotein interactions, but the mechanism is totally unknown. It is clear that Prp43 is the motor to drive the reaction. Another DExD/H-box protein Brr2 has been implicated in disassembly of the spliceosome, but whether its ATPase function is involved remains controversial.

The NTR complex not only mediates disassembly of the spliceosome at the end of the splicing pathway, but can also mediate disassembly of splicing complexes stalled in the middle of the pathway, presumably to prevent accumulation of impaired spliceosomes. NTR can mediate disassembly of the spliceosome arrested specifically after the action of Prp2 and Prp16, suggesting a role of Prp2 and Prp16 in marking the spliceosome for targeting by NTR. This complies with the model of splicing fidelity control by $\mathrm{DExD} / \mathrm{H}$-box proteins initially proposed by Christine Guthrie for Prp16 for its role in proofreading the branchpoint sequence, and later shown by others for Prp2, Prp5, Prp22 and Prp28 through similar mechanisms. In this model, impaired or slow spliceosomes are rejected by DExD/H-box proteins coupling with the energy from ATP hydrolysis. Reducing the ATPase activity allows the spliceosome more chance to proceed through the pathway. Recent biochemical studies on Prp5's role in prespliceosome formation reveal an alternative mechanism for Prp5 in proofreading the branch site sequence independent of its ATPase activity, suggesting that the splicing machinery may use multiple ways for fidelity control.

Through 30 years of studies, new functions of splicing factors and new mechanisms of individual steps are being uncovered. There remain many open questions to be answered. Continuing efforts in structural and mechanistic studies should lead to an ultimate understanding of this complicated process. 

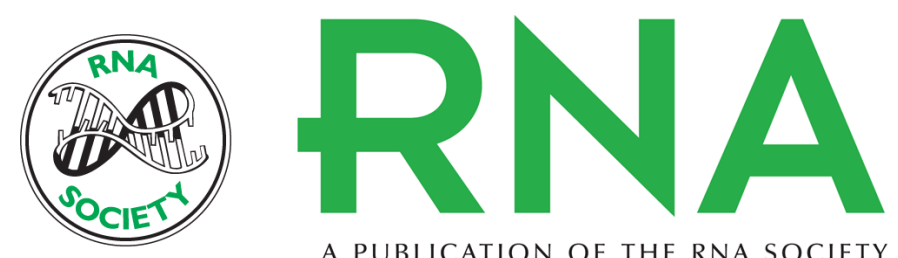

A PUBLICATION OF THE RNA SOCIETY

\title{
RNA splicing for 30 years
}

\author{
Soo-Chen Cheng
}

RNA 2015 21: 586-587

Open Access Freely available online through the RNA Open Access option.

Creative This article, published in $R N A$, is available under a Creative Commons License

Commons (Attribution-NonCommercial 4.0 International), as described at

License http://creativecommons.org/licenses/by-nc/4.0/.

Email Alerting Receive free email alerts when new articles cite this article - sign up in the box at the Service top right corner of the article or click here.

To subscribe to RNA go to:

http://rnajournal.cshlp.org/subscriptions

(C) 2015 Cheng; Published by Cold Spring Harbor Laboratory Press for the RNA Society 